\title{
Leendő és gyakorló biológiatanárok egészségdefinícióinak összehasonlító elemzése
}

\author{
Comparative analysis of future and in-service biology teachers' health \\ definitions
}

Szerzők: $\quad$ Végh Veronika $\bowtie$, Pusztafalvi Henriette

Pécsi Tudományegyetem, Egészségtudományi Kar

Beküldve: 2019. 10. 30.

doi: $\quad$ 10.24365/ef.v61i1.528

\begin{abstract}
Összefoglaló:
Bevezetés: Jelen kutatás célja az volt, hogy felmérje a középiskolában tanító és a leendő biológiatanárok egészségfogalmát. A téma fontosságát indokolja, hogy a biológiaórákon kitüntetett figyelmet kap az egészségnevelés és az egészségfejlesztés, amelyben a pedagógus mintaszerepe hangsúlyosan jelenik meg. Az egyén egészségről kialakult nézetei hatással vannak az egészségmagatartására, így a pedagógusok, mint mintaadók és az óráikon elhangzott tartalmak is befolyásolják a tanulók egészségfelfogását.

Módszertan: 153 gyakorló és 66 leendő biológiatanár vett részt az anonim, önkitöltős kérdőíves felmérésben. Az elemzéskor binomiális tesztet, Chi-négyzet és t-próbát végeztünk.

Eredmények: A mozgás, a táplálkozás és az egészségtudatosság komponensek említésénél szignifikáns eltérést láthatunk a leendő és a gyakorló biológiatanárok egészségdefiníciói között, a leendő tanárok javára. Az Egészségügyi Világszervezet teljes, 1964-es definíciója nem került megfogalmazásra egyik csoportban sem. A leendő biológiatanárok több mint 40\%-a, a gyakorló tanárok több mint 30\%-a egyik definíció komponenst sem jelezte válaszában. A testi-lelki jóllét említése volt a leggyakoribb, a komplexebb testi-lelki-szociális jóllétre hivatkozás a gyakorló tanároknál kis számban ugyan de megjelent, azonban a leendő tanároknál nem. Mindkét csoportban volt olyan válasz, amelyben a testi-lelki jóllét és a betegség hiánya komponensek kerültek megemlítésre. A betegség hiánya komponens a pozitív érzelemmel együtt fordult elő a leggyakrabban.
\end{abstract}

Következtetések: Jövőbeli cél, hogy az egyetemi hallgatók egészségtudatos életmódot folytassanak, valamint, hogy ez a hozzáállásuk megmaradjon a későbbiekben is. Továbbá fontos az is, hogy a középiskolai biológiaórákon is megjelenjen az egészséges életmódra nevelés, melyben jelentős a tanári minta közvetítése. E felelősségteljes feladatkör betöltését, a pedagógusok egészségét támogató programokkal, tréningekkel, a tantárgyba beépíthető egészségfejlesztési tananyagokkal is javasolt támogatni, így a biológiatanár is nagyobb eséllyel formálhatja diákjait az egészséges életmód megvalósítása irányába a mindennapokban.

Kulcsszavak: biológiatanárok; egészség definíció; középfokú oktatás 


\begin{abstract}
Summary:
Introduction: The purpose of this study was to assess future and in-service biology teachers' definition of health. The importance of the topic lies in the fact that health education and health promotion receive special attention in biology classes, in which the model role of the teacher is emphasized. The individual's health behaviour is influenced by his/her perceptions of health, therefore teachers as role models as well as the taught material can also affect it.
\end{abstract}

Methods: 153 in-service and 66 future biology teachers participated in the selfcompleted, anonymous questionnaire survey. During data analysis binomial tests, Chi-square and t-tests were run.

Results: There were significant differences between the future and in-service biology teachers' health definitions in case of the physical exercise, nutrition and health awareness components, for the future teachers' benefit. The complete definition of the World Health Organization from 1946 was not mentioned in any of the groups. More than $40 \%$ of future biology teachers and more than $30 \%$ of in-service biology teachers did not indicate any of the definition components in their answers. Mentioning physical and mental well-being was the most common. Mentioning the more complex physicalmental-social well-being appeared in small numbers among the in-service biology teachers, but did not in the case of future teachers. Physical-mental well-being and the absence of disease were mentioned together in some cases in both groups. The absence of the disease component occurred together with the positive emotion component the most often.

Conclusions: The future goal for university students is to pursue a health conscious lifestyle and to maintain this attitude throughout their life. It is also important to educate pupils for healthy lifestyle in the secondary school biology classes, in which the role of teachers serving as role models is significant. To fulfil this responsible role, teachers should be supported with health-related programs, trainings and in-class health promotion curricula, thus the biology teachers are more likely to shape their students' healthy lifestyle in the course of everyday life.

Keywords: biology teachers; health definition; secondary education

\section{BEVEZETÉS}

Az egészség definíciójának pontos meghatározására régóta törekednek a szakemberek, azonban a feladat nem egyszerú. Számos olyan tényező hatással lehet rá, ami miatt különböző egyének különböző jelentéstartalommal töltik meg az egészségfogalmat. E jelentéstartalmak szétdarabolódása, az interdiszciplináris jelenléte miatt, a különféle professziókban kialakuló egészségfogalmak, a pozitív és negatív definíciók más és más részletekkel magyarázzák az egészség jelenségét. ${ }^{1}$

$\mathrm{Az}$ egészség értelmezésének történelmi távlatai vannak. Már az ókori görögök is felismerték azt, hogy az egyén felelős egészségi állapotáért, valamint a lelki tényezőknek egészségre befolyásoló szerepet tulajdonítottak. A zsidó-keresztény tanítások, a Biblia is több helyen foglalkozik az egészséggel. ${ }^{2}$ A XIV-XVI. században bekövetkezett markáns változások (nagy földrajzi felfedezések, gazdasági fellendülés) megváltoztatták az egészséghez való hozzáállást, az egyének jobban figyeltek önmagukra, boldogulásukra, sorsukra, származásukra és a jövőjükre. Még a latin könyvekben is napvilágot láttak egészséges életvitelről, megfelelő táplálkozásról és ruházkodásról szól szövegek. ${ }^{2,3} \mathrm{~A}$ protestáns mozgalmak korában a könyvnyomtatás volt az, ami fellendítette az egészségről megfogalmazott nézetek terjesztését. A kiadványok főleg a testi egészséggel kapcsolatos írásokat tartalmaztak. ${ }^{2,3}$ 
A XIX-XX. századra a biomedicinális felfogás terjedt el, melyben a betegség gyógyítása és nem az egészség megőrzése volt hangsúlyos. ${ }^{2}$

Végezetül számos felfogásban mutatkozott meg a fogalom, mely a XX. századra előidézte a paradigmaváltást az egészség értelmezésében. Az Egészségügyi Világszervezet (WHO) által 1946-ban leírt definíció kimondja, hogy „az egészség a teljes testi-lelki és szociális jóllét állapota, nem csupán a betegség vagy a fogyatékosság hiánya". ${ }^{4}$ Talán ez a definíció a mai napig az, melyet a legtöbben ismernek. ${ }^{5} \mathrm{~A}$ biomedikális és a pszicho-szociális elméletek mellett Parsons (1972) írásában fizikai-mentális egyensúly állapotaként, Seedhouse (1986) árucikként, míg Dubos (1959) attitűdként kezeli az egészséget. ${ }^{6,7}$ (198.0) A definíció finomítása, kiegészítése többször megtörtént (például: Lalonde jelentés (1974), Ottawai Charta (1975), Antonovsky salutogenesis elmélete (1979)), azonban a mai napig nem alakult ki egy olyan megfogalmazás, melyet minden professzió és felfogás magáénak érezne. ${ }^{8,9,10}$ Emiatt a „Mi az egészség?” kérdésre más és más területek és szemléletek alapján eltérő válaszok születnek.

Érdemes megemlíteni a nemrég napvilágot látott komplex, új egészségértelmezést, a Meikirch modellt. Ez alapján az egészség legfóbb komponensei (melyek kölcsönhatásban állnak egymással) az egyéni faktorok (szükségletek és kihívások alapján), a biológia potenciál és az egészséges társadalmi illetve környezeti tényezők. ${ }^{11}$

Napjaink egészségfogalmai multidiszciplinárisak, valamint dinamikusak. Ahogy Benkő Zsuzsanna megfogalmazza (2019), az egyén egészségi állapotát meghatározzák a természeti és társadalmi környezet, az források mértéke, az egyén problémamegoldó képessége, a sikerélményei illetve az elégedettsége. A mai modellek már folyamatként tekintenek az egészégre. Az egészség, amelyben a pozitív énkép és a testi-lelki egyensúly jelen van az egyén problémamegoldó képességén és az érzelemirányítás képességén át nyilvánul meg. ${ }^{12}$

Az egészségfogalomról és -felfogásról tehát napjainkban elmondható, hogy értelmezése pozitív, annak többdimenziós tulajdonságait veszik figyelembe (testi-, lelki-, szociális jóllét, ökológiai és spirituális szempontok). A jelenlegi értelmezés az egészséget szubjektíven közelíti meg (az objektív helyett), a személyes feltételekre helyezi a hangsúlyt (az organikus feltételek helyett), valamint szituatívan és dinamikusan értelmezi azt. ${ }^{13}$ (21.0) Az egészségfogalmak rendkívül széles fogalmi körét befolyásolják a területi, településbeli, társadalmi, demográfiai jellemzők, ráadásul az egészségfogalom tartalmi különbözőségei miatt a neveléstudományi egészségértelmezésnél még több faktor együttes figyelembevétele szükséges. ${ }^{7}$ Az oktatásban megjelenő egészségnevelés területeinek szétdarabolódására hívja fel a figyelmet a Meleg Csilla által készített 1. ábra, melyen látható, hogy az iskolai egészségnevelés a testi egészségre szúkült. ${ }^{7(187.0)}$ Ez figyelemfelhívó, hiszen az egészséget nem lehet egy komponensként kezelni, komplex halmazba történő elhelyezése szükséges.

A KSH 2016-2017-es adatai alapján Magyarországon a 16 évnél idősebb lakosság szubjektíven megítélt egészségi állapota 59-60\% szerint jó vagy nagyon jó, azonban ez az érték az európai átlag $(67,4 \%)$ alatt van. ${ }^{14}$ A 2014-es Európai lakossági egészségfelmérés (ELEF) adatai alapján pedig a magyar felnőtt lakosság négyötöde véli úgy, hogy sokat tehet saját egészségéért. Ha korcsoport szerinti bontásban vizsgáljuk az adatokat elmondható, hogy a fiatalokra sokkal inkább jellemző, hogy bíznak a saját életmódjuk egészségre gyakorolt hatásában, mint az idősebb válaszadók. ${ }^{15}$

A pedagógusok felelőssége nagy, mivel az iskola is kiemelt színtér, ahol a fiatal korosztálynak meg kell kapnia a megfelelő tudást, tájékozottságot, képességet ahhoz, hogy teljes értékű egészséges életet élhessen mire felnőtté válik, és ezen értékrendet példaként tovább tudja adni majd a jövő nemzedékének.

Az egészséges életmóddal, egészségneveléssel, egészségfejlesztéssel kapcsolatos kutatások számtalan irányból közelítik meg a diákság, valamint az idősebb korosztály egészségfelfogását és azon tényezők megismerését, melyek a preventív egészségmagatartást támogatják. Magyarországon például a teljeskörű iskolai egészségfejlesztés koncepció, a mindennapos testnevelés bevezetése egyre több kutatót inspirál vizsgálódásra. ${ }^{16,17,18}$ Felsőoktatásban tanuló, különböző képzésekben részt vevő hallgatók egészségképét is vizsgálták, miszerint az egészségtan-tanár szakos hallgatók értelmezése egészség-centrikusabb és változatosabb (melyben a prevenció, az egészségnevelés és egészségfejlesztés kifejezettebben megjelenik), mint 
a művelődésszervező vagy a tanító szakon tanuló hallgatók egészségfogalom meghatározása. ${ }^{19}$ Jelen tanulmány mindezt a leendő és gyakorló biológiatanárok oldaláról kísérli meg vizsgálni, kvalitatív adatok statisztikailag kezelhetővé tétele után, összefüggések, trendek leírásával. Reméljük, hogy eredményeink sikerrel bővítik a pedagógusok és a tanárnak készülő egyetemisták egészségével kapcsolatos kutatások palettáját, hiszen a kérdéskör minél sokoldalúbb vizsgálatával közelebb kerülhetünk az oktatási intézményekben megvalósuló hatékonyabb egészségnevelő és egészségfejlesztő munkához.

1. ábra: A köznevelési és az egészségügyi rendszer együttmüködése és az egészségfogalom tartalma

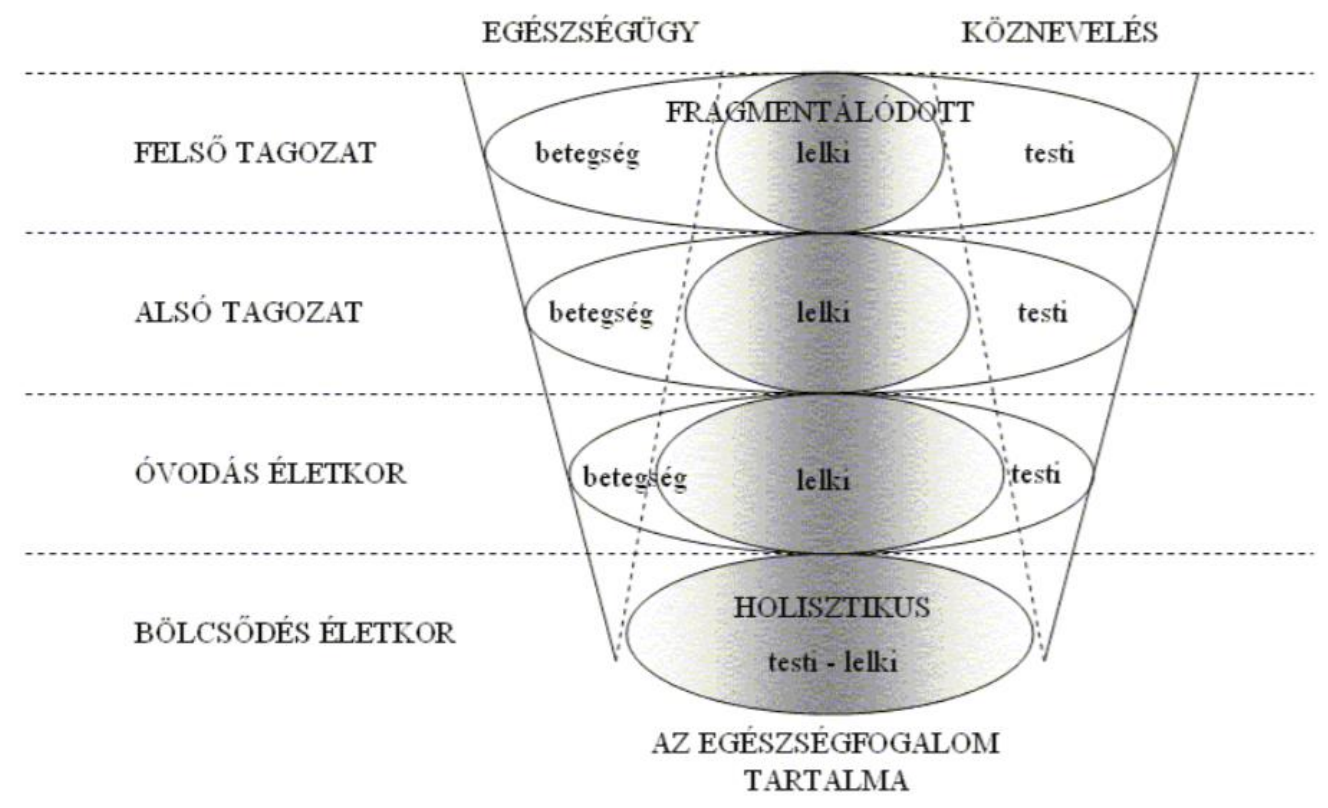

Forrás: Meleg, $2006^{7 \text { (187.o.) }}$

\section{MÓDSZERTAN}

\section{Minta}

Jelen kutatásban a leendő és gyakorló biológiatanárok anonim kérdőívek kitöltésével járultak hozzá önkéntesen a kutatáshoz. A kvalitatív vizsgálat sajátossága az, hogy az egyéni válaszokat statisztikai adatokká kódolja, melyből következtetések vonhatók le. ${ }^{20}$ A középfokú intézményekben tanító biológiatanárokat az intézményvezetőkön keresztül kíséreltük meg elérni. Több mint 500 e-mail üzenetet küldtünk ki az intézményvezetőknek a felkéréssel. 153 biológiatanár válaszolt az online kérdőívre. Magyarországi egyetemeken felkerestünk olyan oktatókat, akik nagy eséllyel találkoztak a biológiatanár-képzésben résztvevő hallgatókkal és lehetőségük volt megosztani velük az online kérdőív linkjét vagy a papír alapú kérdőívet. A biológiatanárképzésben résztvevő hallgatóktól 66 válasz érkezett vissza. Összességében tehát 219 kérdőív elemzése történt meg ebben a kutatásban.

\section{A kérdőív}

A komplex kérdőív kitöltése önkéntes volt és teljesen anonim. A mérőeszközök azonosak voltak a két csoportnál (leendő és gyakorló biológiatanárok), így összehasonlításukra lehetőség adódott. A kérdőív több kérdéskörből épült fel, melyet szakirodalomból átvett kérdőívrészek és saját magunk által szerkesztett kérdések adtak. A kitöltők válaszoltak szocio-demográfiai, alapvető sportolási és étkezési szokásokra vonatkozó, valamint biológiához, 
információs- és kommunikációs technológiához (IKT) és egészségfejlesztéshez kapcsolódó kérdésekre. A megkérdezettek véleményt formáltak továbbá a biológiaórákon megjelenő egészségtani tartalmak ideális oktatási gyakoriságáról és azok megvalósíthatóságának lehetőségeiről, illetve jelen tanulmány legfontosabb kérdésére is választ adtak, melyben azt is leírták, számukra mit jelent az egészség.

\section{Statisztikai elemzés}

A statisztikai elemzéshez IBM SPSS Version 20.0 és Microsoft Excel szoftvereket használtunk. Binomiális teszteket, Chi-négyzet és t-próbákat futtattunk, lehetőség szerint odd-ratiot számoltunk.
Adatainkat 95\%-os megbízhatóság mellett értelmeztük. A definíciók elemzését úgy kezdtük, hogy két, egymástól független kódoló, a válaszok előzetes áttanulmányozása alapján létrehozott kódkönyv szerint lekódolta a megfogalmazásokat. A kódkönyv létrehozásánál törekedtünk arra, hogy a megfogalmazásokat képesek legyünk majd beilleszteni valamely kód alá.

A kódkönyvben megtalálható kódok az alábbiak voltak: WHO, betegség hiánya, testi jóllét, lelki jóllét, szociális jóllét, mozgás, táplálkozás, közömbös, filozófia, egészségtudatosság/helyes életmód, pozitív érzelem, testsúly, hosszú élet, minden, nyugalom. A két kódoló egyezési százalékait és a kódok alatt megjelenő tipikus kifejezéseket, választípusokat az 1. táblázat tartalmazza.

1. táblázat: A két kódoló egyezési százalékai és a kódok alatt megjelenő tipikus válaszok

\begin{tabular}{|c|c|c|}
\hline Kód neve & Egyezési \% & Példák a kódok alatt megjelenő válaszokra \\
\hline WHO & 0,959091 & $\begin{array}{l}\text { Jelen kód teljes megemlítésére nem volt példa, az alábbi definíciót } \\
\text { kerestük: „Az egészség a teljes testi, szellemi és szociális jóllét } \\
\text { állapota, nem pusztán a betegség vagy fogyatékosság hiánya.” }\end{array}$ \\
\hline testi jóllét & 0,936364 & $\begin{array}{l}\text { "olajozott fizikális múködés”, „,testi épség”, , „a szervezet megfelelo” } \\
\text { múködése”, „,fittség”, „,testi jóllét” }\end{array}$ \\
\hline lelki jóllét & 0,9 & $\begin{array}{l}\text { „kiegyensúlyozott lelki állapot”, „lelki egészség”, „lelki egyensúly”, } \\
\text { „lelki jóllét” }\end{array}$ \\
\hline szociális jóllét & 1 & „Szzociális jóllét” \\
\hline betegség hiánya & 0,918182 & $\begin{array}{l}\text { „nem vagyok beteg”, „fogyatékosság hiánya”, „nem fáj semmim”, } \\
\text { „a testem panaszmentes működése” }\end{array}$ \\
\hline mozgás & 0,990909 & $\begin{array}{l}\text { „,rendszeres testmozgás”, „mozgásban aktív mindennapok”, } \\
\text { „megfelelő fizikai aktivitás”, }\end{array}$ \\
\hline táplálkozás & 0,968182 & $\begin{array}{l}\text { „tudatos táplálkozás”, „változatos étkezés”, „olyan dolgokat eszem, } \\
\text { hogy jó hatással legyenek rám”, }\end{array}$ \\
\hline közömbös & 0,945455 & „Nem gondolok arra, hogy jól vagyok-e"," ...nem érdekel” \\
\hline filozófia & 0,890909 & $\begin{array}{l}\text { „szellemiség”, ” ... a lehető legjobb állapotban lenni”, } \\
\text { „kiegyensúlyozott élet”, „önmagam megvalósítása” }\end{array}$ \\
\hline $\begin{array}{l}\text { egészségtudatos- } \\
\text { ság/helyes életmód }\end{array}$ & 0,886364 & $\begin{array}{l}\text { „rendszeres szürések”, „a testem tükrözi a lelkiállapotom és } \\
\text { fordítva- tehát mindkettő gondozása számomra az egészség”, } \\
\text { „életmód tudatos választása” }\end{array}$ \\
\hline pozitív érzelem & 0,845455 & $\begin{array}{l}\text { "jókedv”, „harmónia”, „jól érezni magunkat a bőrünkben”, } \\
\text { „jó közérzet”, „jó kedélyek”, „jó hangulat," }\end{array}$ \\
\hline testsúly & 0,995455 & „„ideális testsúly megőrzése”, „a testsúly és a stressz legyőzése” \\
\hline hosszú élet & 1 & „a hosszú élet titkát” \\
\hline mindent & 0,995455 & „mindent", „életet” \\
\hline nyugalom & 0,945455 & „nyugodtság”, „stresszmentes életmód” \\
\hline
\end{tabular}

Forrás: saját szerkesztés 
Ahogy látható az egyezési százalékokon, három esetben látható 0,9 alatti érték. Ezek a következő kódok voltak: pozitív érzelem, egészségtudatosság/helyes életmód, filozófia. Ezen eltéréseknek az oka egyrészt az volt, hogy a „jó közérzet” definíció értelmezése nem volt egységes. Az első kódoló a filozófiához, a második a pozitív érzelemhez csoportosította. Az átnézést követően a „jó közérzet” megfogalmazást megegyezés alapján a pozitív érzelem kategóriába soroltuk. Másik ok volt az, hogy az egyik kódoló azokat a definíciókat, melyeket nem lehetett beilleszteni egyik kifejezés alá sem a filozófiához tette, a másik kihagyta. Az egészségtudatosság/ helyes életmód kód tekintetében pedig az eltérés abból származott, hogy az egyik kódoló szúkebben értelmezte a kódolást; ott ahol ugyan megvoltak az egészségtudatosságra/helyes életmódra mutató gondolatok a megfogalmazásban, de nem került megemlítésre közvetlen módon az egészségtudatosság, a helyes táplálkozási és egyéb szokások vagy a figyelem az egészségre, nem adott pontot. Ellenben a másik kódoló az egészségtudatosság/ helyes életmód kódot tágabban értelmezte, ennél fogva akkor is adott pontot, ha az adott egészségdefiníció tartalmi elemei az egészségtudatosságra és a helyes életmódra való törekvésre vonatkoztak. A kódokat megvizsgálva a tágabb értelmű kódok használata mellett döntöttünk.

\section{EREDMÉNYEK}

\section{Az értelmezhető változók kiszűrése}

Több kategóriánál látható, hogy rendkívül ritkán említik a leendő és a gyakorló biológiatanárok, és ha 1-1 kategória említése túl alacsony, akkor nem lehetséges a csoportok összehasonlítását elvégezni a kategóriák tekintetében. Annak érdekében, hogy meg tudjuk határozni azokat a változókat, amelyek már nem értelmezhetők, binomiális tesztet végeztünk, így ellenőriztük, hogy a válaszok nem túl egyoldalúak-e. Azokat a változókat tartottuk meg, melyeknek az előfordulása szignifikánsan magasabb volt, mint 10\%. [2. táblázat]

2. táblázat: A kategóriák megjelenésének aránya, p értékük és értelmezésük

\begin{tabular}{|c|c|c|c|}
\hline & $\begin{array}{c}\text { A kategória } \\
\text { megjelenésének aránya }\end{array}$ & $p$ & Értelmezés \\
\hline Betegség hiánya & $21,40 \%$ & $<0,001$ & \multirow{8}{*}{$\begin{array}{l}\text { A kategóriák értelmezhetők, } \\
\text { mivel előfordulási arányuk } \\
\text { szignifikánsan } 10 \% \text { felett van. }\end{array}$} \\
\hline Testi jóllét & $51,16 \%$ & $<0,001$ & \\
\hline Lelki jóllét & $46,51 \%$ & $<0,001$ & \\
\hline Mozgás & $17,21 \%$ & 0,001 & \\
\hline Táplálkozás & $19,07 \%$ & $<0,001$ & \\
\hline Filozófia & $14,88 \%$ & 0,015 & \\
\hline Egészségtudatosság & $14,88 \%$ & 0,015 & \\
\hline Pozitív érzelem & $22,79 \%$ & $<0,001$ & \\
\hline WHO definíció & $0,00 \%$ & $<0,001$ & \multirow{7}{*}{$\begin{array}{l}\text { A kategóriák nem használha- } \\
\text { tók, mert előfordulási ará- } \\
\text { nyuk nem éri el a } 10 \% \text {-ot. }\end{array}$} \\
\hline szociális jóllét & $3,20 \%$ & $<0,001$ & \\
\hline Közömbös & $1,86 \%$ & $<0,001$ & \\
\hline Testsúly & $0,93 \%$ & $<0,001$ & \\
\hline Hosszú élet & $0,93 \%$ & $<0,001$ & \\
\hline Mindent & $0,93 \%$ & $<0,001$ & \\
\hline Nyugalom & $6,05 \%$ & 0,028 & \\
\hline
\end{tabular}

Forrás: saját szerkesztés 
A leendő és gyakorló biológiatanárok definícióinak eltérései

Chi-négyzet próbával elemeztük, hogy a leendő és a gyakorló biológiatanárok között van-e szignifikáns különbség a definíciók kódolásait követő kategóriák említésének arányában. A binomiális tesztekkel vizsgáltuk, hogy a tanárok egy adott kategóriát inkább említenek vagy nem, a vizsgált aránymutató $50 \%$ volt. A teszt azt ellenőrizte, hogy a tanárok 1-1 kategóriát fele-fele aránynál szignifikánsan kevésbé vagy esetlegesen jobban említettek. [3. táblázat]

A betegség hiánya kategóriát a leendő biológiatanárok 25\%-a, míg a hivatásukat gyakorlók tanárok közül 20\% említette. A testi jóllét kategóriát megközelítőleg fele-fele arányban írták le, a két csoport között a különbség nem volt szignifikáns. A lelki jóllét kategóriát a gyakorló biológiatanárok 50\%-a említette, míg a leendő biológiatanárok esetében ez csak $40 \%$ volt. A csoportok között azonban a lelki jóllét kód esetén sem számolhatunk be szignifikáns eltérésről.

A mozgást a leendő biológiatanárok 26\%-a, a gyakorlóknak csupán a 13\%-a jelezte az egészség leírásánál. Köztük az eltérés szignifikáns, a leendő biológiatanárok 2,3-szor gyakrabban említették a mozgást a gyakorló biológiatanároknál (Or=2,302). A táplálkozást a leendő biológiatanárok 32\%-a, míg a gyakorló biológiatanárok 13\%-a fogalmazta meg az egészség definiálásánál, mely eltérés köztük szignifikáns, a leendő tanárok háromszor nagyobb eséllyel említették azt (Or=3,102).

A filozófia kategória a leendő biológiatanárok 12\%-ánál, a gyakorló biológiatanárok 16\%-ánál fordult elő, közöttük nem szignifikáns az eltérés.

Az egészségtudatosságot a leendő biológiatanárok 24\%-a, a gyakorló biológiatanárok 11\%-a foglalta írásba. A különbség köztük szignifikáns, a leendő biológiatanárok 2,7-szer gyakrabban említették azt, mint a gyakorló tanárok (Or=2, 735).

A pozitív érzelem megjelenése mindkét csoport esetén 25\% alatti, a leendő tanároknál 24\%, a gyakorló biológiatanároknál 22\% volt. A két csoport között nem szignifikáns a különbség a kategória említésében.

A teszt eredményei alapján létrejött három csoportot a 4. táblázat mutatja be.

3. táblázat: A leendő és gyakorló tanárok definícióinak különbségei

\begin{tabular}{|c|c|c|c|c|c|c|c|c|}
\hline & \multicolumn{2}{|c|}{ Válasz megjelenésének aránya } & \multicolumn{4}{|c|}{$\begin{array}{l}\text { Pearson Chi-négyzet } \\
2 \text { csoport } \\
\text { összehasonlítására }\end{array}$} & \multicolumn{2}{|c|}{ Binomiális teszt 50\%-hoz } \\
\hline & $\begin{array}{c}\text { leendő } \\
\text { biológiatanárok }\end{array}$ & $\begin{array}{c}\text { gyakorló } \\
\text { biológiatanárok }\end{array}$ & $x^{2}$ & $d f$ & $p$ & phi & $\begin{array}{c}\text { leendő } \\
\text { biológiatanárok }\end{array}$ & $\begin{array}{c}\text { gyakorló } \\
\text { biológiatanárok }\end{array}$ \\
\hline Betegség hiánya & $24,62 \%$ & $20,00 \%$ & 0,574 & 1 & 0,449 & $-0,052$ & 0,000 & 0,000 \\
\hline Testi jóllét & $46,15 \%$ & $53,33 \%$ & 0,936 & 1 & 0,333 & 0,066 & 0,620 & 0,463 \\
\hline Lelki jóllét & $38,46 \%$ & $50,00 \%$ & 2,427 & 1 & 0,119 & 0,106 & 0,082 & 1,000 \\
\hline Mozgás & $26,15 \%$ & $13,33 \%$ & 5,232 & 1 & 0,022 & $-0,156$ & 0,000 & 0,000 \\
\hline Táplálkozás & $32,31 \%$ & $13,33 \%$ & 10,579 & 1 & 0,001 & $-0,222$ & 0,006 & 0,000 \\
\hline Filozófia & $12,31 \%$ & $16,00 \%$ & 0,488 & 1 & 0,485 & 0,048 & 0,000 & 0,000 \\
\hline $\begin{array}{l}\text { Egészségtuda- } \\
\text { tosság }\end{array}$ & $24,62 \%$ & $10,67 \%$ & 6,965 & 1 & 0,008 & $-0,18$ & 0,000 & 0,000 \\
\hline Pozitív érzelem & $24,62 \%$ & $22,00 \%$ & 0,176 & 1 & 0,675 & $-0,029$ & 0,000 & 0,000 \\
\hline
\end{tabular}

Forrás: saját szerkesztés 
2. ábra: A leendő és gyakorló biológiatanárok válaszainak kódolását követöen kialakult komponensekre osztott válaszok aránya

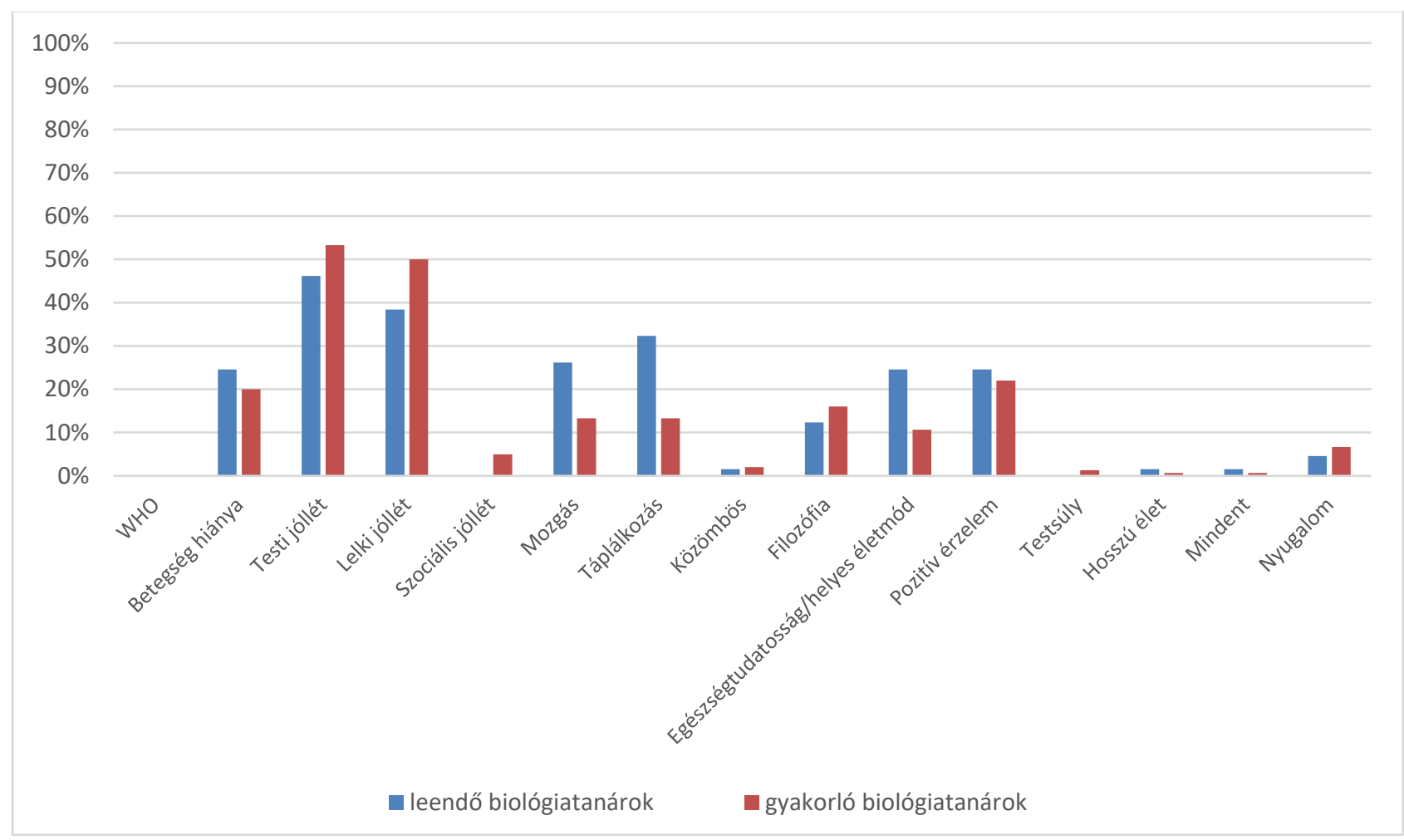

Forrás: saját szerkesztés

4. táblázat: A kódolt definíció komponensek eloszlása

\begin{tabular}{|l|l|l|l|}
\hline \multicolumn{1}{|c|}{ Csoport } & \multicolumn{1}{|c|}{1.} & \multicolumn{1}{|c|}{2.} & \multicolumn{1}{c|}{3.} \\
\hline Magyarázat & $\begin{array}{l}\text { Azok a változók tartoznak ide, } \\
\text { melyek nem értelmezhetők, } \\
\text { mivel 10\%-nál kevesebbszer ír- } \\
\text { ták a tanárok. }\end{array}$ & $\begin{array}{l}\text { Ezek a változók használhatók } \\
\text { ugyan, de Chi-négyzet próba } \\
\text { eredményei alapjän nincs } \\
\text { a leendő és a gyakorló tanárok } \\
\text { válaszait összehasonlítva. }\end{array}$ & $\begin{array}{l}\text { Ezek a változók használhatók } \\
\text { és szifikáns különbség van a } \\
\text { válaszaiban. Minden esetben } \\
\text { a leendő biológiatanárok } \\
\text { felülmúlták a gyakorló bioló- } \\
\text { giatanárok válaszait. }\end{array}$ \\
\hline $\begin{array}{l}\text { Definíció } \\
\text { komponensek }\end{array}$ & $\begin{array}{l}\text { WHO, szociális jóllét, közöm- } \\
\text { bös, testsúly, hosszú élet, min- } \\
\text { dent, nyugalom }\end{array}$ & $\begin{array}{l}\text { betegség hiánya, testi jóllét, } \\
\text { lelki jóllét, filozófia, pozitív ér- } \\
\text { zelem }\end{array}$ & $\begin{array}{l}\text { egészségtudatosság/helyes } \\
\text { életmód, mozgás, táplálkozás }\end{array}$ \\
\hline
\end{tabular}

Forrás: saját szerkesztés

\section{A WHO (1946) definíció komponenseinek megjelenése}

A WHO (1946) eredeti definíciójának komponenseit vizsgáltuk az elemzés következő részében, mivel, (ahogyan arra a bevezetőben is tettünk utalást) feltételezhetően ez az az egészségdefiníció, ami a köztudatban a mai napig a legjobban ismert.

A testi jóllét, a lelki jóllét, a szociális jóllét és a betegség hiánya változókat vizsgáltuk. A teljes definíció hiányát (a 2. ábrán is láthatjuk) a szociális komponens említésének hiánya okozza főleg. 
A 3. ábra mutatja, hogy a testi és a lelki jóllét komponensek mindkét csoport esetén magasak voltak, a szociális jóllét a leendő biológiatanároknál nem jelent meg, a gyakorló biológiatanároknál elenyésző volt. A betegség hiányát a leendő biológiatanárok kicsit nagyobb százalékban említették, mint a gyakorló biológiatanárok.
T-próbával ellenőriztük, hogy a két csoport milyen mértékben adta meg a WHO teljes definíciójának komponenseit $(\mathrm{t}(213)=1,207, \mathrm{p}=0,229)$. Ez alapján megállapítottuk, hogy nincs szignifikáns különbség a két csoport között. [4. ábra]

3. ábra: A leendő és a gyakorló biológiatanárok esetében a WHO (1946) definíció komponenseinek említési gyakoriságai

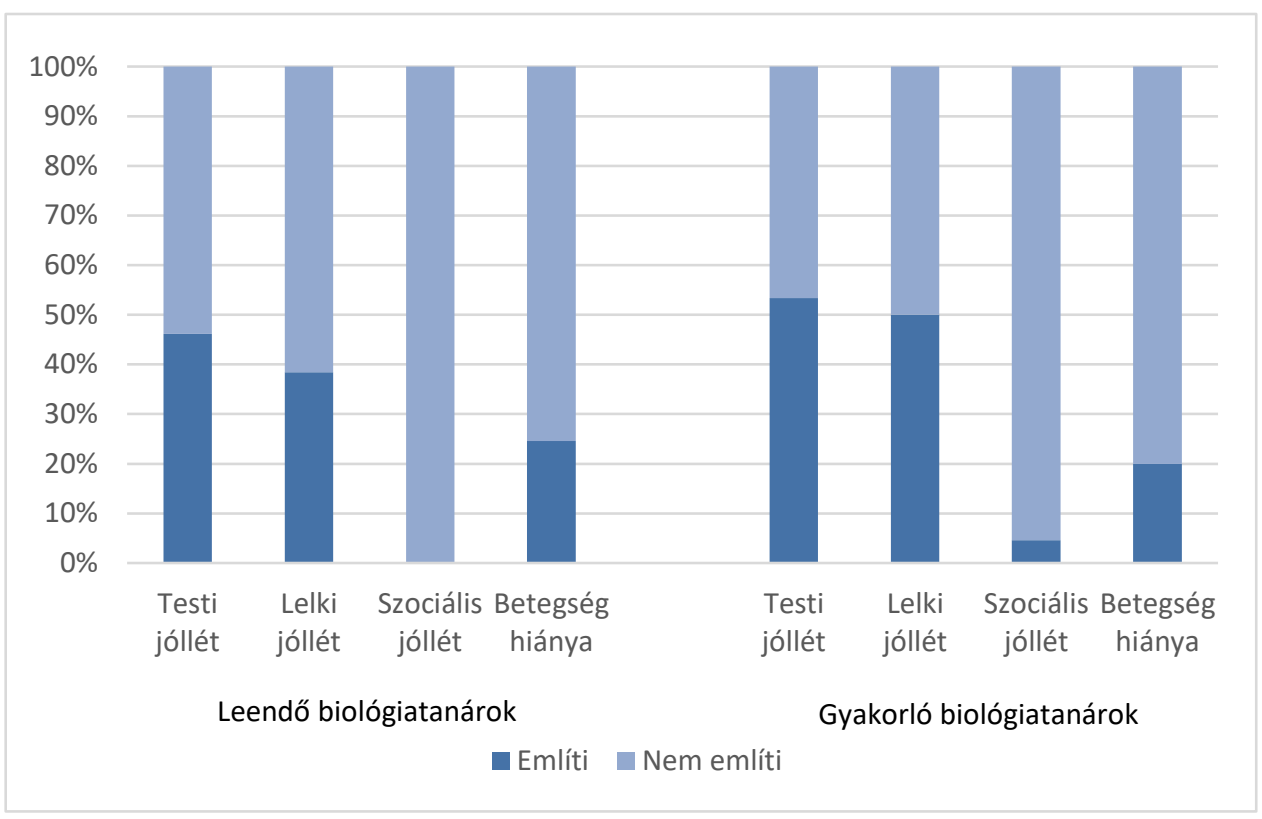

Forrás: saját szerkesztés

4. ábra: A leendő és a gyakorló biológiatanárok esetében a WHO (1946) definíció komponenseinek említési száma

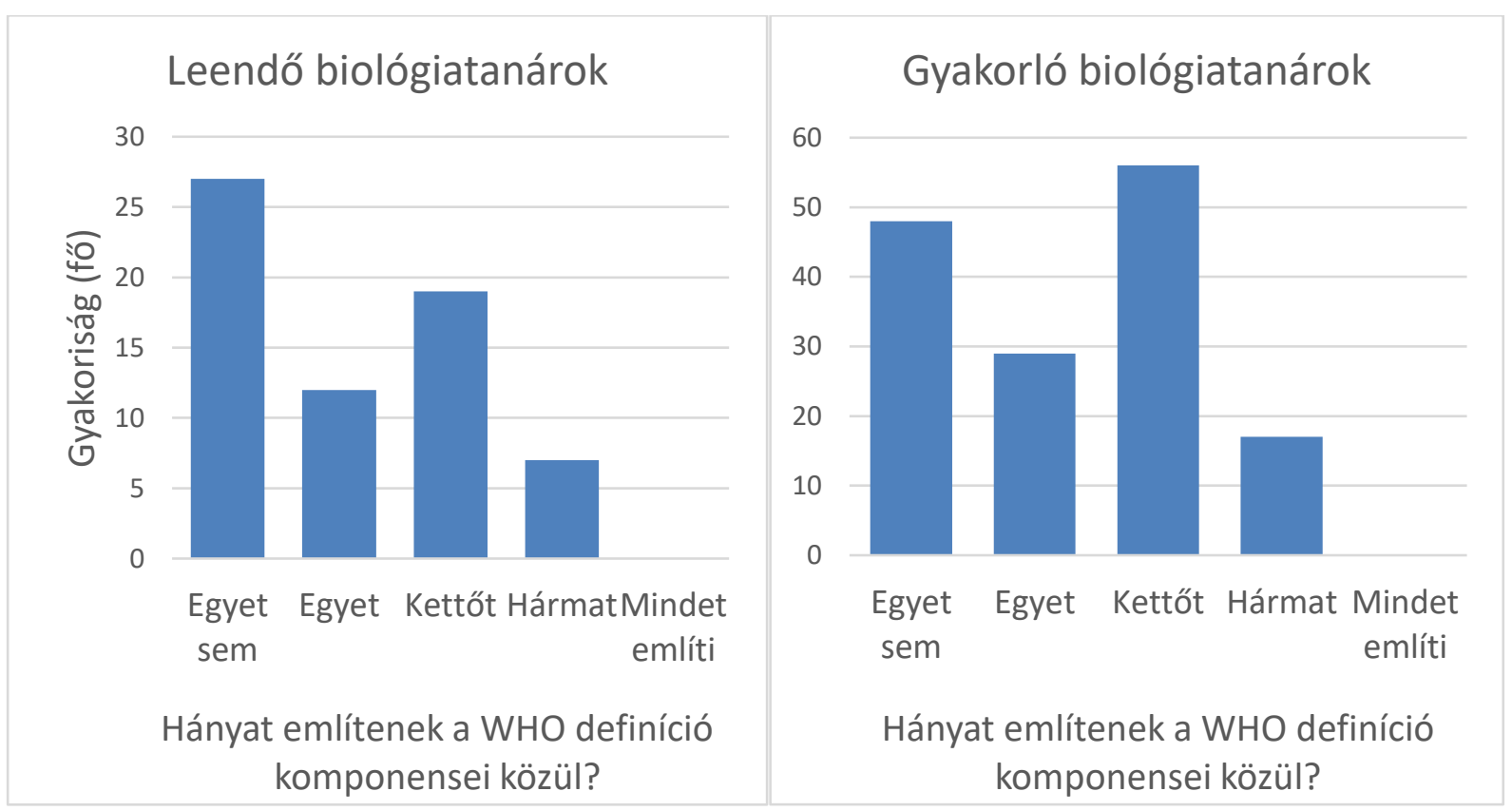

Forrás: saját szerkesztés 
5. táblázat: A tanárok esetében a WHO egészségdefinició (1946) komponensei emlitésének százalékos arányai

\begin{tabular}{|l|c|c|}
\hline & $\begin{array}{c}\text { Leendő } \\
\text { biológiatanárok }\end{array}$ & $\begin{array}{c}\text { Gyakorló } \\
\text { biológiatanárok }\end{array}$ \\
\hline csak testi jóllét & $7,58 \%$ & $5,23 \%$ \\
\hline csak lelki jóllét & $1,52 \%$ & $3,92 \%$ \\
\hline csak szociális jóllét & $0,00 \%$ & $0,00 \%$ \\
\hline csak betegség hiánya & $9,09 \%$ & $9,80 \%$ \\
\hline egyiket sem említette & $40,91 \%$ & $30,72 \%$ \\
\hline testi-lelki jóllét & $24,24 \%$ & $33,99 \%$ \\
\hline testi-szociális jóllét & $0,00 \%$ & $0,00 \%$ \\
\hline testi jóllét-betegség hiánya & $3,03 \%$ & $2,61 \%$ \\
\hline lelki-szociális jóllét & $0,00 \%$ & $0,00 \%$ \\
\hline lelki jóllét-betegség hiánya & $1,52 \%$ & $0,65 \%$ \\
\hline szociális jóllét-betegség hiánya & $0,00 \%$ & $0,00 \%$ \\
\hline testi-lelki-szociális jóllét & $0,00 \%$ & $4,58 \%$ \\
\hline testi-lelki jóllét-betegség hiánya & $10,61 \%$ & $6,54 \%$ \\
\hline testi-szociális jóllét-betegség hiánya & $0,00 \%$ & $0,00 \%$ \\
\hline lelki-szociális jóllét-betegség hiánya & $0,00 \%$ & $0,00 \%$ \\
\hline testi-lelki-szociális jóllét-betegség hiánya & $0,0 \%$ \\
\hline
\end{tabular}

Forrás: saját szerkesztés

Az 5. táblázat mutatja, hogy ahol megjelent mégis a szociális jóllét, ott a testi-lelki-szociális jóllét kontextusban fogalmazták meg a tanárok, a gyakorló biológiatanárok 4,58\%-a míg a leendő biológiatanárok 0\%-a.

A betegség hiánya komponens a definícióban úgy jelenik meg, mint szükséges, de nem elégséges feltétele az egészségnek. A betegség komponens vagy a testi-lelki jóllét és betegség hiánya összefüggéseként vagy csak magában a betegség hiánya említéseként volt jelen mindkét csoportban. Az összes említett betegség hiánya változó a többi változó közül a pozitív érzelemmel együtt került megemlítésre a leggyakrabban (leendő biológiatanárok: 37,5\%, gyakorló biológiatanárok: 20\%).

A testi-lelki jóllét megemlítése mindkét csoportban párban volt jelen a leggyakrabban (leendő biológiatanárok: 24\%, gyakorló biológiatanárok: 34\%). Aki csak a testi jóllétet vagy a lelki jóllétet magában említette, ott inkább a testi jóllét említése volt a jellemző. Az egyiket sem említők százalékos aránya magas (leendő biológiatanárok: 41\%, gyakorló biológiatanárok: 31\%).

\section{Egyéb válaszok}

Felmerül a kérdés, hogy azok, akik egyik komponenst sem említették, mit adtak meg helyette. A 6. táblázat mutatja, hogy sokan nevezték meg a mozgást és a táplálkozást főleg a leendő biológiatanárok közül. Azok a gyakorló tanárok, akik nem említették a WHO definíciót, főleg filozófia kategóriába tartozó válaszokat adtak. 
6. táblázat: A biológiatanárok egyéb válaszainak százalékos előfordulása

\begin{tabular}{|l|c|c|}
\hline & $\begin{array}{c}\text { Leendő } \\
\text { biológiatanárok }\end{array}$ & $\begin{array}{c}\text { Gyakorló } \\
\text { biológiatanárok }\end{array}$ \\
\hline Mozgás & $48,15 \%$ & $20,83 \%$ \\
\hline Táplálkozás & $59,26 \%$ & $22,92 \%$ \\
\hline Közömbös & $3,70 \%$ & $6,25 \%$ \\
\hline Filozófia & $25,93 \%$ & $45,83 \%$ \\
\hline Egészségtudatosság & $40,74 \%$ & $20,83 \%$ \\
\hline Pozitív érzelem & $22,22 \%$ & $22,92 \%$ \\
\hline Testsúly & $0,00 \%$ & $4,17 \%$ \\
\hline Hosszú élet & $3,70 \%$ & $2,08 \%$ \\
\hline Mindent & $3,70 \%$ & $2,08 \%$ \\
\hline Nyugalom & $11,11 \%$ & $10,42 \%$ \\
\hline
\end{tabular}

Forrás: saját szerkesztés

\section{MEGBESZÉLÉS ÉS KÖVETKEZTETÉSEK}

A pedagógusok szerepe a mintaadásban nem vonható kétségbe, az is tudott, hogy a diákok egészségmagatartására a környezetben megjelent minták hatnak. ${ }^{21} \mathrm{Az}$ iskola nevelési koncepciójában lényeges az, hogy az élethez közelítve történjen. ${ }^{22}$ Az oktatási intézmények keretein belül megvalósuló egészségfejlesztésben egyik legfontosabb szerep a pedagógusoké. A jelen tanulmányban bemutatott biológiatanár populáció kifejezetten érintett a kérdéskörben, hiszen az általuk oktatott tantárgy információtartalmai támogatni tudják a diákok egészségtani tudását, a tanári mintával példamutatásukkal még inkább hatással lehetnek neveltjeikre. Fontos kiemelni azonban azt, hogy a biológiatanárok munkája közel sem azonos a korábban létező egészségtan- és az egészségfejlesztés tanárokéval. A biológiatanárok óráin az egészségfogalom a biológia tantárgy részeként jelenik meg, amit, jelen kutatásból látható, hogy nem kifejezetten a komplex szemlélet jellemez. Az egészségtan- és az egészségfejlesztés tanárok pedig a komplex egészségfogalomra építve tanulmányaikat, önállóan foglalkoztak a témával.
Eredményeink alapján elmondható, hogy a megfogalmazások szerint kialakult kategóriák nem mindegyike volt felhasználható a további elemzésekre, az alacsony megjelenés miatt. A binomiális teszt segítségével kiszűrt kódok, melyek a további vizsgálatokban is megmaradtak az alábbiak voltak: betegség hiánya, testi jóllét, lelki jóllét, mozgás, táplálkozás, filozófia, egészségtudatosság és a pozitív érzelem.

Ezeket magyarázhatjuk azzal, hogy a világon feltételezhetően a legjobban ismert 1946-os WHO definíció komponensei közé tartoznak a testi jóllét, a lelki jóllét, a betegség hiánya változók. ${ }^{5} \mathrm{~A}$ mozgás és a helyes táplálkozás napjainkban, mint két lényeges egészségvédő faktor ismeretes. Somhegyi is kiemeli, hogy az egészséges táplálkozás, a rendszeres aktivitás, a lelki egészség támogatása a legfontosabb iskolai egészségfejlesztő tevékenységek közé tartoznak. ${ }^{16}$ A megfelelő mennyiségű és minőségú mozgás, a helyes táplálkozás természetesen feltételez egyfajta egészségtudatosságot is, így a jelen tanulmányban megjelenő komponensek jelenléte érthető. A filozófia és a pozitív érzelem kategóriák pedig holisztikus értékrendről árulkodnak. 
Összehasonlítva a leendő és a gyakorló biológiatanárok válaszait a fentebb említett kategóriákra, háromszor jelent meg szignifikáns eltérés közöttük, minden esetben a leendő biológiatanárok javára. A mozgás, a táplálkozás és az egészségtudatosság komponensek említésénél voltak megfigyelhetők ezek a különbségek. Így elmondható, hogy az egyetemi hallgatók egészségdefiníciójában szignifikánsan többször megjelentek ezek a válaszok.

A mozgás és a táplálkozás azok a változók, amelyek a primer prevenció lényeges komponensei a kialakult kódrendszerben, tehát ezek markáns részei az egészségmegőrzésnek. Ebben a tekintetben a leendő biológiatanárok egészségtudatosabb, preventívebb magatartásról számoltak be a gyakorló biológiatanároknál. Ez a megállapításunk összhangba hozható a 2014-es ELEF vizsgálatokkal, miszerint a fiatalabb korosztályra jellemző a pozitív felfogás, véleményük szerint az életmódjukkal nagymértékben befolyásolhatják egészségüket. A mért különbségek részben a biológiatanár-képzés változásaiból is eredhetnek. A jelenlegi, osztatlan biológiatanár-képzésben az egészségtan tantárgy jelen van, azonban a korábbi bolognai rendszerben vagy az azt megelőző két szakos tanárképzésben az egészségtan önálló szakként, vagy biológiaegészségtan tanár szakpárként volt jelen.

Megjegyzendő, hogy nincs olyan kategória, ami az egészségdefiníció fókusza lett, ahol 50-50\%-nál nagyobb arányban került volna megemlítésre valamelyik fogalomkör. Erőteljes asszociációról jelen mintában tehát nem számolhatunk be.

A WHO (1946) definíció komponenseinek megjelenésével külön részben foglalkoztunk annak érdekében, hogy feltérképezzük előfordulásukat, illetve a két csoport közti esetleges eltéréseket. Sem a leendő sem a gyakorló biológiatanárok nem írták le a 4 komponenst (testi-, lelki-, szociális jóllét, betegség hiánya) együtt, melynek oka legnagyobb részben a szociális jóllét komponens megjelenésének a hiánya volt. A gyakorló tanárok esetében néhányszor a testi-lelki-szociális jóllét hármas egység megemlítésre került, a leendő biológiatanároknál azonban erre nem volt példa.
A betegség hiánya komponens említése is elmaradt a testi és a lelki jóllét komponensektől, melynek előfordulása vagy csak magában vagy a testi-lelki jólléttel hármas egységben foglalt helyet. Ebben szerepe lehet az egészségdefiníció első részének jól memorizált mivoltában. A betegség hiánya komponens a pozitív érzelemmel jelent meg közösen a leginkább. A testi-lelki jóllét mindkét csoportban döntően együtt fordult elő, de ha csak egymagukban kerültek megemlítésre, akkor a testi jóllét volt a jellemző. A bevezetőben említett, főiskolás hallgatók egészségképét vizsgáló kutatás alapján a lelki, szellemi, érzelmi kategória (32,24\%) érvényesült a legjobban az egyetemi hallgatók válaszaiban, majd az életmód és a testi kategóriák követték azt. ${ }^{19}$ Mintánkban a leendő biológiatanárok 41\%-a, illetve a gyakorló biológiatanárok 31\%-a egyik komponenst sem említette a 4 közül.

Eredményeink alapján látható, hogy a biológiatanárok egészségfogalmai meglehetősen sokfélék, melyekben számos egyéni befolyásoló tényező felfedezhető, így egységes jellemzésükre nincs lehetőség. Abban azonban megegyezik az összes kitöltő, hogy hivatásuk és szerepkörük által közvetített személyes értékeikkel a tanulók életmódjára hatást gyakorolnak.

Kutatásunk a jelen és jövő biológiatanár populáció egészségértelmezésének egy kis szeletét mutatta be, mely más kutatások eredményeivel társítva, hozzájárulhat a biológiatanárok egészségfogalmának minél részletesebb megismeréséhez. A profeszszió szerepkörében ez fontos, mivel a biológiatanárok a tananyagátadással és mintanyújtással a felnövekvő nemzedék egészségtudatosabb magatartását sikerrel támogathatják.

\section{KÖSZÖNETNYILVÁNÍTÁS}

A szerzők köszönetüket szeretnék kifejezni Dr. Soltész-Várhelyi Klárának az elemzésben nyújtott támogatásáért, valamint Kottász Kata Boglárkának a kódolásban nyújtott segítségéért. 


\section{HIVATKOZÁSOK}

\footnotetext{
${ }^{1}$ Meleg Cs. Iskolai egészségfejlesztés: a feladat újrafogalmazása. Magyar Pedagógia, 2002. 102 évf. 1. szám 11-29.

2 Tarkó K, Benkő Zs. „Az egészség nem egyetlen tett, hanem szokásaink összessége”. Szemelvények egy multidiszciplináris egészségfejlesztő múhely munkáiból. Szegedi Egyetemi Kiadó Juhász Gyula Felsőoktatási Kiadó, Szeged, 2016. ISBN 9786155455681.

${ }^{3}$ Kéri K. Az egészség kultúrtörténeti megközelítése (az ókortól a 18. századig). In: Kállai J., Varga J., Oláh, A., (2007, szerk.): Egészségpszichológia a gyakorlatban. II. rész, II. fejezet. Medicina Könyvkiadó Zrt., Budapest, 37-50. ${ }^{4}$ World Health Organization (1946): Preamble to the Constitution of the World Health Organization, as adopted by the International health Conference, New York, 19-22 June, 1946, Basic Documents, Fourty-eight edition, 2014:1. (http://apps.who.int/gb/bd/PDF/bd48/basic-documents-48th-edition-en.pdf) (Elérve: 2019.10.30.)

${ }^{5}$ Lampek K, Füzesi Zs. Az egészség fogalmának alakulása. In K. Tarkó, \& L. Lippai, „GYÜMÖLCS? A FA BEVÁLTJA AZT, AMIT VIRÁGÁVAL ÍGÉRT." Tanulmányok Benkő Zsuzsanna 60. születésnapjára (old.: 41-68). Szeged: SZTE JGYPK Alkalmazott Egészségtudományi és Egészségfejlesztési Intézet. 2013.

${ }^{6}$ Fináncz J, Csima M. A kora gyermekkori nevelésben dolgozók egészségi állapotának és egészségmagatartásának mutatói. Képzés és Gyakorlat, 2019. 17.évf. 1. szám 25-40.

${ }^{7}$ Meleg Cs. Az iskolai egészségnevelés koncepcionális keretei. In I. Bárdossy, K. Forrai R., \& K. Kéri, Tananyagok a pedagógia szakos alapképzéshez (old.: 191-213). Bölcsész Konzorcium: Budapest. 2006.

${ }^{8}$ Lalonde M. (1974): A new perspective on the health of Canadians. Government of Canada.

http://www.phac-aspc.gc.ca/ph-sp/pdf/perspect-eng.pdf (Elérve: 2019.10.30.)

${ }^{9}$ WHO (1986): The Ottawa Charter for Health Promotion. http://www.who.int/healthpromotion/conferences/ previous/ottawa/en/ (Elérve: 2019.10.30.)

${ }^{10}$ Antonovsky A. The salutogenic model as a theory to guide health promotion. Health Promotion International, 1996. 11, 11-18. (Elérve: 2019.10.30.)

${ }^{11}$ Csizmadia P. Az egészség fogalmának újradefiniálására a Meikirch modell. Egészségfejlesztés. 2018. LIX.évf., 2018. 1. szám., 45-51.

12 Benkő Zs. Az egészség történeti és modern megközelítése. Az egészségfejlesztés fogalma, szemléletmódja In Benkő Zsuzsanna, Lippai László, Tarkó Klára (szerk.): Az egészség az életünk tartópillére. Egészségtanácsadási kézikönyv. JGYF Kiadó. Szeged. .2019. 978615594606 06. 15-49.o.

13 Benkő Zs. Egészségfejlesztés. Módszertani kézikönyv. Mozaik kiadó. Szeged. 2009. ISBN: 9789636975807

${ }^{14}$ https://www.ksh.hu/docs/hun/xftp/stattukor/egeszsegallapot1617.pdf (Elérve: 2019.10. 30.)

${ }^{15}$ http://www.ksh.hu/docs/hun/xftp/idoszaki/elef/elef2014 osszefoglalo.pdf (Elérve: 2019.10.30.)

${ }^{16}$ Somhegyi A. Teljeskörű iskolai egészségfejlesztés (TIE): jelen helyzet. Különleges Bánásmód. 2016. II. évfolyam 4.szám. 61-80. Letöltés dátuma: 2019. augusztus 13, forrás: http://real.mtak.hu/81191/1/KB2016-4-061-M-0001-3365XXXX0Somhegyi.pdf

${ }^{17}$ Meszlényi E, Urbinné Borbély S, Seregi E, Morvay-Sey K, \& Rétsági E. A mindennapos testnevelés néhány kérdésének vizsgálata. Sport és egészségtudományi füzetek. 2017. 1. évfolyam 1. szám/2017. 8-18. Letöltés dátuma: 2019. augusztus 21, forrás: http://etk.pte.hu/public/upload/files/Sport es egtudomanyi fuzetek/SETF 0101.pdf

${ }_{18}$ Meszlényi E. Vizsgálat a 2012-ben bevezetett mindennapos testnevelés gyakrolati megvalósításáról a szegedi iskolák körében. Sport és Egészségtudományi Füzetek, 2017. I. évfolyam 1. szám/2017.

${ }^{19}$ Szarvasné Mátó V, \& Benkő Zs. Főiskolai hallgatók egészségképe összehasonlító vizsgálat . Magyar Pedagógia, 2006. 107-127.

${ }^{20}$ Pethőné Csima M. Kvalitatív kutatási módszerek szerepe az egészségmagatartás vizsgálatában. Vzdelávanie, výskum a metodológia. 2013. old.: 149-154.

${ }^{21}$ Pikó B. Az életmód elemei: szabadidő és az egészség-magatartás. In Barabás K. (szerk), Egészségfejlesztés Alapismeretek pedagógusok számára. Medicina. Budapest. 2006.

22 Tókos K. Az önismeret-jelenismeret tanítója, fejlesztője: az „új arcú”, reflektív pedagógus. Új Pedagógiai Szemle. 2005. 12.
} 